\title{
Combined DFT and XPS Investigation of Cysteine Adsorption on the Pyrite (1 00 ) Surface
}

\author{
Xingfu Zheng ${ }^{1,2,+}$, Xuan Pan ${ }^{1,2, \dagger}$, Zhenyuan Nie ${ }^{1,2, *}$, Yi Yang ${ }^{1,3}$, Lizhu Liu ${ }^{1,2}$, Hongying Yang 4 \\ and Jinlan Xia ${ }^{1,2, *}$ \\ 1 School of Minerals Processing and Bioengineering, Central South University, Changsha 410083, China; \\ zhengxingfu@csu.edu.cn (X.Z.); panxuan@csu.edu.cn (X.P.); yi.yang@csiro.au (Y.Y.); \\ liulizhu@csu.edu.cn (L.L.) \\ 2 Key Lab of Biometallurgy of Ministry of Education of China, Central South University, \\ Changsha 410083, China \\ 3 Commonwealth Scientific and Industrial Research Organisation (CSIRO Mineral Resources), \\ Clayton 3169, Victoria, Australia \\ 4 School of Metallurgy, Northeastern University, Shenyang 110819, China; yanghy@smm.neu.edu.cn \\ * Correspondence: zynie@csu.edu.cn (Z.N.); jlxia@csu.edu.cn (J.X.); \\ Tel.: +86-731-8883-6044 (Z.N.); +86-731-8883-6944 (J.X.) \\ + These authors have equally contributed to this work.
}

Received: 6 August 2018; Accepted: 21 August 2018; Published: 23 August 2018

\begin{abstract}
The adsorption of cysteine on the pyrite $\left(\begin{array}{lll}1 & 0 & 0\end{array}\right)$ surface was evaluated by using first-principles-based density functional theory (DFT) and X-ray photoelectron spectroscopy (XPS) measurements. The frontier orbitals analyses indicate that the interaction of cysteine and pyrite mainly occurs between HOMO of cysteine and LUMO of pyrite. The adsorption energy calculation shows that the configuration of the - $\mathrm{OH}$ of $-\mathrm{COOH}$ adsorbed on the Fe site is the thermodynamically preferred adsorption configuration, and it is the strongest ionic bond according to the Mulliken bond populations. As for Fe site mode, the electrons are found transferred from cysteine to Fe of pyrite (1 00 ) surface, while there is little or no electron transfer for S site mode. Projected density of states (PDOS) is analyzed further in order to clarify the interaction mechanism between cysteine and the pyrite $\left(\begin{array}{lll}1 & 0 & 0\end{array}\right)$ surface. After that, the presence of cysteine adsorption on the pyrite $\left(\begin{array}{lll}1 & 0 & 0\end{array}\right)$ surface is indicated by the qualitative results of the XPS spectra. This study provides an alternative way to enhance the knowledge of microbe-mineral interactions and find a route to improve the rate of bioleaching.
\end{abstract}

Keywords: bioleaching; cysteine; pyrite; surface adsorption; DFT calculations; XPS

\section{Introduction}

Bioleaching technology plays an important role in cost-effective recovery of valuable metals from low-grade sulfide mineral resources [1]. During bioleaching, the sulfide minerals are attacked by $\mathrm{Fe}^{3+}$, producing elemental sulfur and other sulfur compounds as well as $\mathrm{Fe}^{2+}$ that are further oxidized by bioleaching microorganisms to provide $\mathrm{Fe}^{3+}$ and $\mathrm{H}^{+}$for the further dissolution of sulfide minerals [2]. The bioleaching process actually involves complicated solution-mineral-microorganisms multiphase interface interactions, in which the microbe-mineral interface interaction plays a decisive role [3,4]. Macroscopic phenomena such as dissolution, precipitation, transformation, and synthesis of minerals are caused by micro-scale microbe-mineral interactions during the bioleaching process [5]. Microbial adsorption is an important process of mineral-microbe interface interactions. After being adsorbed on the mineral surface, the microbial cells' secretion of extracellular organic matter increases significantly. The biofilms formed by bridging of extracellular organic matter are the main sites 
for microbe-mineral interaction [6-8]. Thus, the biomolecule-mineral interaction determines the microbe-mineral interactions that affect the leaching effect. Moreover, many studies [9-12] have suggested that pyrite surfaces resulting from crystallographic structure changes could selectively bind to simple amino acid residues. Thus, research on the adsorption mechanisms of simple organic molecules on pyrite surfaces is significant for understanding microbe-mineral interface interaction.

It is known that cysteine is one of the most reactive amino acid residues due to its reductive -SH group, which may play a key role in binding proteins to sulfide minerals, in which it may improve interfacial electron transfer [13-15]. There is no doubt that research on the interaction between cysteine and minerals can be helpful in evaluating the interfacial interaction between extracellular proteins of microbes and sulfide mineral surface. Both the effect of cysteine on bioleaching and the adsorption mechanism of cysteine on sulfide minerals have been reported [15-19], but none of these cases were subject to interfacial interaction between cysteine and the mineral surface.

During recent years, the interface between microorganisms and minerals has been widely explored. The adsorption of various small molecules on pyrite has been extensively explored by means of first-principles based on density functional theory (DFT). By DFT, Yang et al. [20] have discerned the adsorption, reaction, and desorption mechanisms of mercury over the pyrite surface, and proved that $\mathrm{HgS}$ was chemically adsorbed on pyrite $\left(\begin{array}{lll}1 & 0 & 0\end{array}\right)$ and the charge accumulation around the sulfur atom. The group of Jianhua Chen [21-24] studied the interaction of $\mathrm{O}_{2}$ with pyrite $\left(\begin{array}{lll}1 & 0 & 0\end{array}\right)$ by DFT, and found that electron transfer from pyrite $\left(\begin{array}{lll}1 & 0 & 0\end{array}\right)$ to $\mathrm{O}_{2}$ simulated the process of electron transfer in sulfide flotation and found that the interaction between xanthate and pyrite is controlled by the energy of valence band. They also investigated the occurrence of gold in pyrite and its effects on the electronic and structural details, simulated single, mono-, and multilayer water adsorptions on the pyrite $\left(\begin{array}{lll}1 & 0 & 0\end{array}\right)$ surfaces by DFT. The importance of increasing attention to the adsorption of small molecules on pyrite surfaces was demonstrated by these works. Moreover, spectroscopic techniques such as X-ray photoelectron spectroscopy (XPS), Raman spectroscopy, and Fourier transform infrared spectroscopy (FTIR) were applied to in situ investigation of the chemical reactions at the pyrite surface. Ganbaatar et al. [9] studied the interaction between amino acids and pyrite surfaces by Raman and AFM. In addition, the features and mechanisms of metal ions and small molecules' adsorption on pyrite have been investigated in previous XPS studies [25-29]. As a consequence, it is effective to utilize DFT and XPS methods for clarifying the mechanisms of molecule adsorption on pyrite $\left(\begin{array}{lll}1 & 0 & 0\end{array}\right)$.

To date, there has been no report on combining DFT calculation and XPS measurements to explore the bioleaching-related interfacial interaction between cysteine and sulfide minerals. So, in order to elucidate the adsorption mechanism of cysteine on sulfide mineral surfaces, in the present study, we choose pyrite $\left(\mathrm{FeS}_{2}\right)$, one of the most important and abundant minerals on the earth and in gold deposits [30], to evaluate the adsorption of cysteine on pyrite $\left(\begin{array}{lll}1 & 0 & 0\end{array}\right)$ by means of first-principles-based DFT calculation, and verify it by XPS measurements. This may enhance our understanding of microbe-mineral interactions and be helpful to find a way to improve the rate of bioleaching.

\section{Computational and Experimental Methods}

\subsection{Computational Details}

A single crystalline cube pyrite belongs to the space group Th6-Pa3 with four formula units of $\mathrm{FeS}_{2}$ per unit cell [31], with Fe atoms located at each of the corners and the centers of all the cube faces. Each Fe atom coordinates with six adjacent $S$ atoms; each $S$ atom is tetrahedrally coordinated by three Fe atoms and one S atom with the S2 dimer formed [24]. Based on the density functional theory (DFT), all the calculations were performed using Cambridge Sequential Total Energy Package (CASTEP), generalized gradient approximation of Perdew-Burke-Ernzenhof (GGA-PBE) of Materials Studio $7.0[32,33]$. Only valence electrons were considered explicitly through the use of ultrashort pseudopotentials [34]. Based on the test results, the cut-off energy was $340 \mathrm{eV}$ and k-points was $2 \times 2 \times 1$ for all calculations. After getting the pyrite $\left(\begin{array}{lll}1 & 0 & 0\end{array}\right)$ surface, which is the most stable surface of 
pyrite [35], a $2 \times 2 \times 1$ supercell was built with a vacuum slab of $15 \AA$ [36]. In all slab calculations, the top most three surface layers of S-Fe-S were allowed to relax while the other layers remained fixed at positions consistent with bulk pyrite [37]. The $\mathrm{pH}$ for bioleaching ranges from 1.0 to 3.0, so a model of the protonated cysteine was built, which was then placed inside a $15 \times 15 \times 15 \AA$ slab for optimization. The convergence tolerances were set to the maximum displacement of $0.002 \AA$, the maximum force of $0.05 \mathrm{eV} / \AA$, the maximum energy change of $2.0 \times 10^{-5} \mathrm{eV} /$ atom under the maximum stress of $0.1 \mathrm{GPa}$. The SCF convergence tolerance was set to $2.0 \times 10^{-6} \mathrm{eV} / \mathrm{atom}$. Spin polarized was considered for all the calculations.

The frontier orbitals (HOMO and LUMO) of pyrite and cysteine were calculated by DMol3 after optimization by CASTEP. All the calculations were performed with GGA-PBE functional, Monkhorst-Pack k-point of Gamma, a fine quality and SCF convergence threshold of $1.0 \times 10^{-6} \mathrm{eV} /$ atom [38].

\subsection{Experimental Details}

L-Cysteine (Sigma-Aldrich Co., St. Louis, MO, USA) was dissolved in deoxygenated ultrapure water to a concentration of $1 \mathrm{mg} / \mathrm{L}(\mathrm{pH} 2)$. A single crystalline cube pyrite used in this study was provided by the School of Minerals Processing and Bioengineering, Central South University, Changsha, China. Combining inductively coupled plasma atomic emission spectrometry (ICP-AES) and energy-dispersive $\mathrm{X}$-ray analysis (EDS) analysis showed the pyrite contained: $44.984 \%$ of $\mathrm{Fe}$, $52.111 \%$ of $\mathrm{S}, 1.287 \%$ of $\mathrm{SiO}_{2}, 0.27 \%$ of $\mathrm{Al}, 0.24 \%$ of $\mathrm{Ca}, 0.09 \%$ of $\mathrm{Ti}$, and $0.018 \%$ of $\mathrm{Co}$. The X-ray diffraction spectrum (XRD) (Figure 1a) indicated that the pyrite sample was absolutely pure compared with the previous work [39]. Some pretreatment of pyrite samples was applied before carrying out the adsorption experiments. The mineral samples were cut into small slices using a Lab Cutter device (MC-120, Maruto, Fukuoka, Japan). After cutting, the pyrite samples were polished with 200 to $3500 / 5000$ sandpaper and cleaned by ultrasonication in ethyl alcohol solution and deionized water to remove any possible contaminants and secondary oxides from the surface. Thereafter, the pyrite samples were dried under a vacuum. The XRD for the dried, treated sample (Figure 1b) indicated the structure of pyrite $\left(\begin{array}{ll}1 & 0\end{array}\right)$. The pyrite samples were stored under a vacuum for subsequent experiments. For adsorption experiments, the pyrite samples were placed in 100-mL beakers containing $40 \mathrm{~mL}$ cysteine solution at room temperature. The beakers were sealed with sterile sealing membranes.

The X-ray photoelectron spectroscopy (XPS) measurements were performed at beamline 4B9B of Beijing Synchrotron Radiation Facility, Beijing, China. A $2.5 \mathrm{GeV}$ electron storage ring and current of $250 \mathrm{~mA}$ were used during experiment. The spot size of incident light in XPS is about $2 \times 0.8 \mathrm{~mm}^{2}$. The samples were taped to the center of the sample holder and put into the ultra-high vacuum chamber of $10^{-9} \mathrm{~Pa}$ for data acquisition. An incident photon energy of $720 \mathrm{eV}$ and a step size of $0.05 \mathrm{eV}$ were used during fine scanning of $\mathrm{C} 1 \mathrm{~s}, \mathrm{~N}$ 1s, O 1s, and S $2 \mathrm{p}$ photoelectron spectroscopy, and an incident photon energy of $900 \mathrm{eV}$ and a step size of $0.05 \mathrm{eV}$ were used during fine scanning of Fe $2 p$ photoelectron spectroscopy. The variable photon energies were calibrated with a fresh $\mathrm{Au}$ polycrystalline film. Curve fitting and peak analysis of XPS data were conducted using CasaXPS 2.3.16 software. After tests, the energy peaks of photoelectron spectra of samples were calibrated by the characteristic peaks of $284.6 \mathrm{eV}$ of $\mathrm{C} 1 \mathrm{~s}$. 

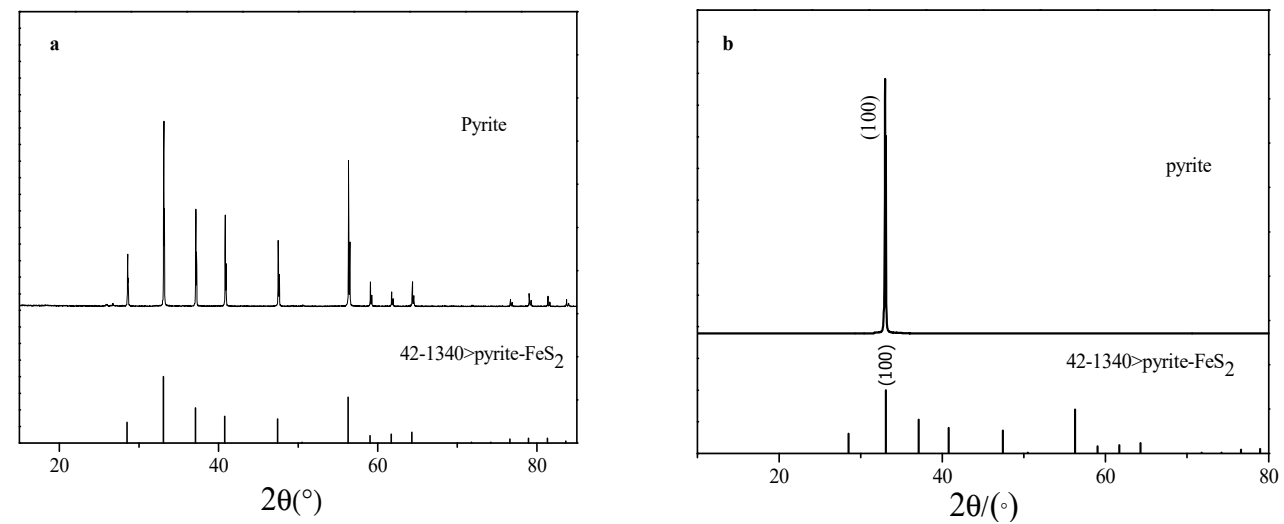

Figure 1. X-ray diffraction (XRD) patterns of powder pyrite (a), and pyrite $\left(\begin{array}{lll}1 & 0 & 0\end{array}\right)$ (b).

\section{Results and Discussion}

\subsection{Bulk Pyrite Calculation}

Comparing with experimental [20] and previous calculation parameters $[35,40]$, the pyrite bulk parameters were optimized to build the pyrite $\left(\begin{array}{lll}1 & 0 & 0\end{array}\right)$ surface and validate the methodology. The bulk pyrite after optimizing is shown in Figure 2. The results of lattice parameters are in Table 1. It is obvious that our calculation results with the smallest error value of $0.22 \%$ are in good agreement with the experimental data, indicating that the calculation methods can provide reliable results for evaluating of cysteine adsorption on the pyrite $\left(\begin{array}{lll}1 & 0 & 0\end{array}\right)$ [20].

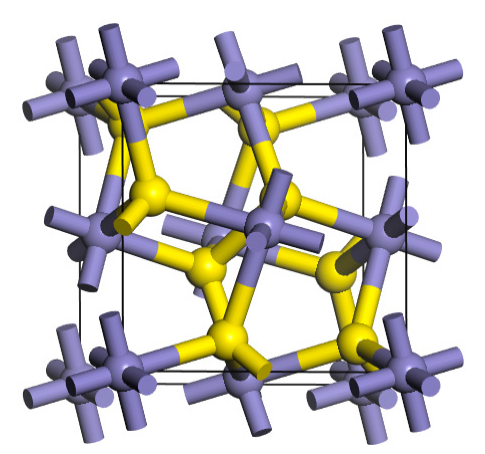

Figure 2. Optimized pyrite unit cell.

Table 1. Optimized lattice parameters (in $\AA$ ) of bulk pyrite $\left(\begin{array}{lll}1 & 0 & 0\end{array}\right)$.

\begin{tabular}{ccc}
\hline $\mathbf{A}=\mathbf{B}=\mathbf{C}$ & & Percent Error \\
\hline 5.416 & Experimental [20] & - \\
5.428 & Present work & $0.22 \%$ \\
5.449 & Previous work [35] & $0.61 \%$ \\
5.431 & Previous work [40] & $0.28 \%$ \\
\hline
\end{tabular}

\subsection{Frontier Orbitals Analyses of Pyrite and Cysteine}

Frontier orbital theory deems that HOMO and LUMO orbitals determine the properties of molecules. The interaction between pyrite $\left(\begin{array}{lll}1 & 0 & 0\end{array}\right)$ and cysteine molecule was evaluated by the inverse proportion in energy of HOMO, which donates electrons, and LUMO, which accepts electrons [41]. In another word, the smaller the absolute value of energy difference is, the more beneficial the interaction will be. Table 2 shows the frontier orbital energies results of HOMO and LUMO for pyrite 
and cysteine and the absolute values of $\Delta \mathrm{E}_{1}$ and $\Delta \mathrm{E}_{2}$, from which it can be seen that the interaction mainly occurs between LUMO of pyrite and HOMO of cysteine rather than HOMO of pyrite and LUMO of cysteine.

Table 2. Frontier orbital energies of pyrite $\left(\begin{array}{lll}1 & 0 & 0\end{array}\right)$ and cysteine.

\begin{tabular}{ccccc}
\hline & HOMO & LUMO & $\Delta \mathrm{E}_{\mathbf{1}}$ & $\Delta \mathrm{E}_{\mathbf{2}}$ \\
\hline Pyrite & -5.829 & -4.672 & 4.062 & 0.158 \\
Cysteine & -4.83 & -1.767 & & \\
\cline { 2 - 4 } $\mathrm{E}_{1}=$ & $\left|\mathrm{E}\left(\mathrm{HOMO}_{\text {pyrite }}\right)-\mathrm{E}\left(\mathrm{LUMO}_{\text {cysteine }}\right)\right| ; \Delta \mathrm{E}_{2}=\left|\mathrm{E}\left(\mathrm{HOMO}_{\text {cysteine }}\right)-\mathrm{E}\left(\mathrm{LUMO}_{\text {pyrite }}\right)\right|$.
\end{tabular}

\subsection{Cysteine Adsorption on the Pyrite (1 00 ) Surface}

Several typical configurations are optimized by considering different initial orientation of cysteine, as shown in Figure 3, with the $-\mathrm{SH}(1 \mathrm{~A}, 1 \mathrm{~B}),-\mathrm{NH}_{3}(2 \mathrm{~A}, 2 \mathrm{~B}),=\mathrm{O}(-\mathrm{C}=\mathrm{O}, 3 \mathrm{~A}, 3 \mathrm{~B}),-\mathrm{O}(-\mathrm{C}-\mathrm{OH}, 4 \mathrm{~A}, 4 \mathrm{~B})$ of cysteine adsorbed on the pyrite $\left(\begin{array}{lll}1 & 0 & 0\end{array}\right)$, respectively. The lengths of the bones for the adsorption configurations are shown in Table 3. It shows that after optimization, the lengths $(\AA)$ between -S-S, -S-Fe, -N-S, -N-Fe, =O-S, =O-Fe, -O-S, and -O-Fe are 3.027, 2.330, 3.009, 2.176, 3.280, 2.171, 3.018, and 2.155, respectively. From the lengths, we can get that the interaction between cysteine and Fe is stronger than that between cysteine and S. Moreover, when -O adsorbs on the S site (4A in Figure 3), the lengths $(\AA)$ between $-\mathrm{NH}_{3}$ and the Fe atom nearby is 2.144 , which may enhance the adsorption of -O; And when -O adsorbs on the Fe site (4B in Figure 3), the lengths $(\AA)$ between $=\mathrm{O},-\mathrm{NH}_{3}$ and the Fe atoms nearby are also very close $(1.973,2.090)$, which means that $-\mathrm{O},=\mathrm{O}$, and $-\mathrm{NH}_{3}$ react with $\mathrm{Fe}$ atoms of the surface in case 4B (Figure 3). This suggests that the adsorption energy of case 4B (Figure 3 ) is the most negative.

The lengths $(\AA)$ of groups of cysteine before and after adsorption are shown in Table 4 . The results show that when cysteine adsorbs on site Fe, the bond lengths $(\AA)$ of $-\mathrm{C}-\mathrm{S},-\mathrm{C}-\mathrm{N},-\mathrm{C}=\mathrm{O}$, and $-\mathrm{C}-\mathrm{O}$ are $1.828,1.522,1.234$, and 1.493 , respectively. All of them are larger than the bond lengths before adsorption, which is because the atoms react with Fe of pyrite $\left(\begin{array}{lll}1 & 0 & 0\end{array}\right)$ and then the bonds with $\mathrm{C}$ atoms are elongated. When cysteine adsorbs on site $\mathrm{S}$, the bond lengths of $-\mathrm{C}-\mathrm{N},-\mathrm{C}=\mathrm{O}$ and $-\mathrm{C}-\mathrm{O}$ are not much changed compared with that before adsorption, which means that there is no or less interaction between cysteine and $S$ of pyrite $\left(\begin{array}{lll}1 & 0 & 0\end{array}\right)$. The bond length $(\AA)$ of $-C-S$ after adsorption is 1.805 , shorter than before adsorption (1.818), which may be because of the repulsion between the $S$ atoms. In addition, the bond length $(\AA)$ of $-\mathrm{S}-\mathrm{H}$ of cysteine in $1 \mathrm{~B}$ is 1.369 , larger than before adsorption (1.350), which means the tendency of cleavage of $-\mathrm{S}-\mathrm{H}$ is in favor of the adsorption, and the result is in good agreement with the previous calculation [42].

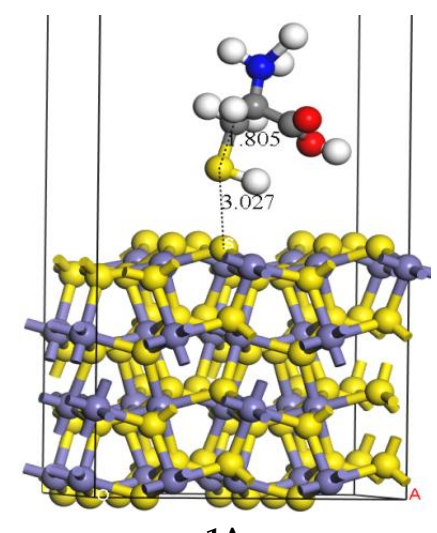

1A

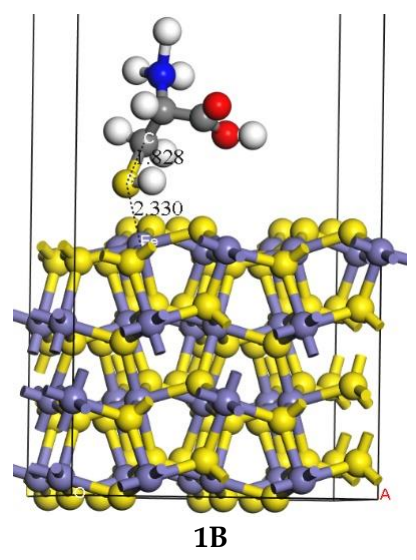

Figure 3. Cont.

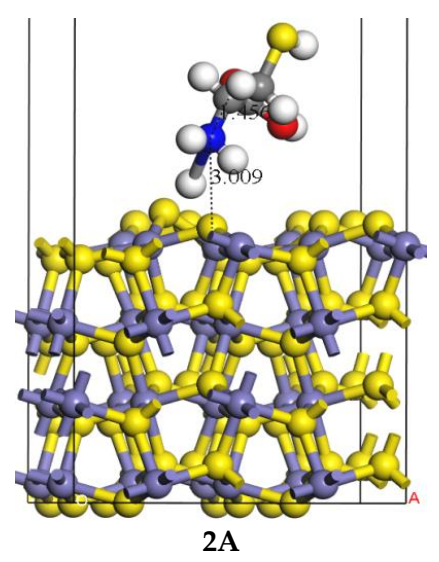

2A 

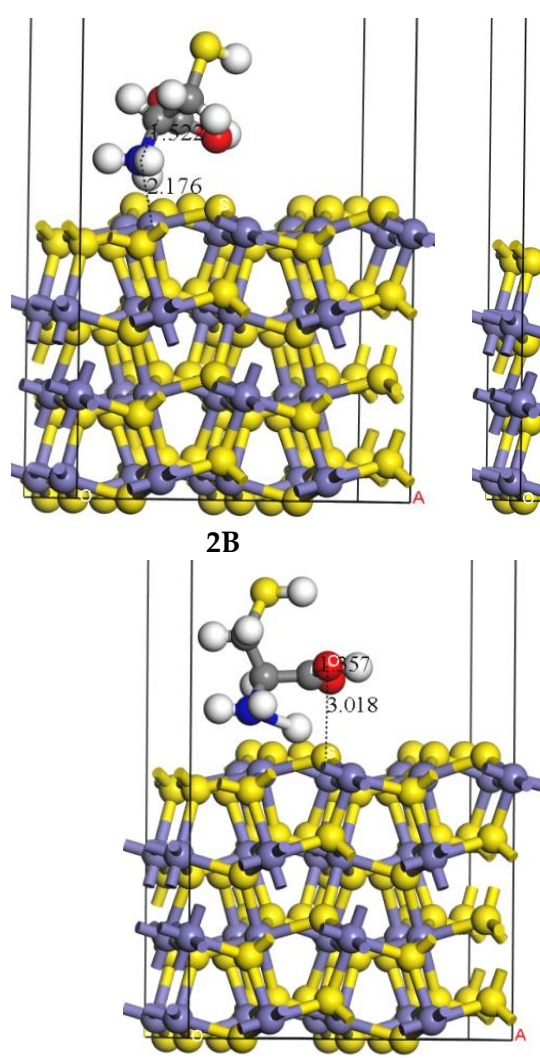

$4 \mathrm{~A}$

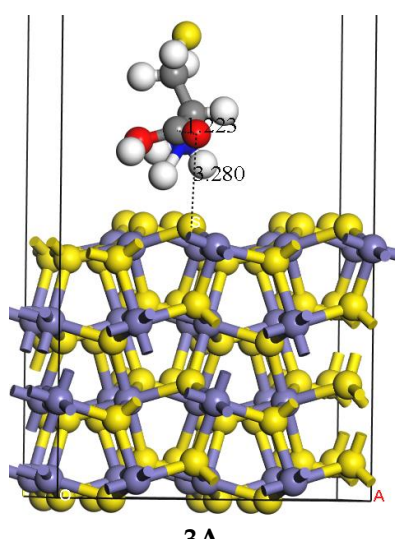

3A

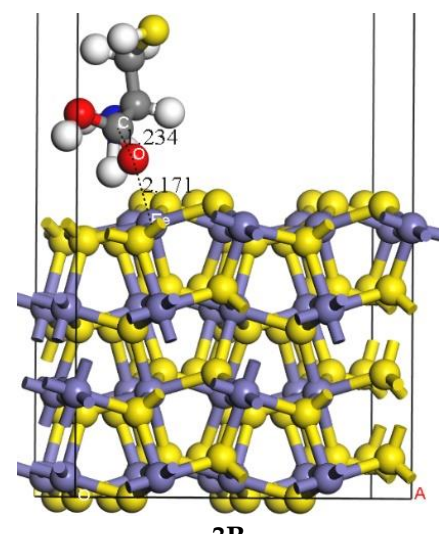

3B

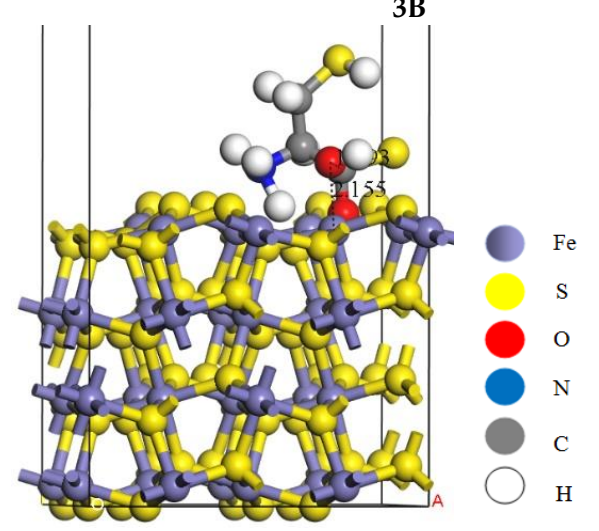

4B

Figure 3. The optimized configuration of cysteine adsorbed on the pyrite $\left(\begin{array}{lll}1 & 0 & 0\end{array}\right)$, showing with -SH $(1 \mathrm{~A} / 1 \mathrm{~B}),-\mathrm{NH}_{3}(2 \mathrm{~A} / 2 \mathrm{~B}),=\mathrm{O}(-\mathrm{C}=\mathrm{O}, 3 \mathrm{~A} / 3 \mathrm{~B}),-\mathrm{O}(-\mathrm{C}-\mathrm{OH}, 4 \mathrm{~A} / 4 \mathrm{~B})$ of cysteine adsorbed on the $\mathrm{S} / \mathrm{Fe}$ site of pyrite $\left(\begin{array}{lll}1 & 0 & 0\end{array}\right)$, respectively.

Table 3. The lengths $(<3.5 \AA)$ between adsorbed atoms of cysteine and pyrite $\left(\begin{array}{llll}1 & 0 & 0\end{array}\right)$ in optimized configuration.

\begin{tabular}{ccc}
\hline Optimized Configuration & Bond & Lengths $(\AA)$ \\
\hline 1A & $-\mathrm{S}-\mathrm{S}$ & 3.027 \\
1B & $-\mathrm{S}-\mathrm{Fe}$ & 2.330 \\
2A & $-\mathrm{N}-\mathrm{S}$ & 3.009 \\
2B & $-\mathrm{N}-\mathrm{Fe}$ & 2.176 \\
3A & $=\mathrm{O}-\mathrm{S}$ & 3.280 \\
3B & $=\mathrm{O}-\mathrm{Fe}$ & 2.171 \\
3B & $-{ }^{*}-\mathrm{S}$ & 3.237 \\
4A & $-\mathrm{O}-\mathrm{S}$ & 3.018 \\
4A & $-{ }^{*}-\mathrm{Fe}$ & 2.144 \\
4B & $-\mathrm{O}-\mathrm{Fe}$ & 2.155 \\
4B & $={ }^{*}-\mathrm{O} e$ & 1.973 \\
4B & $-{ }^{*}-\mathrm{Fe}$ & 2.090 \\
\hline
\end{tabular}

* The atoms nearby the investigated atom. 
Table 4. The lengths values $(\AA)$ of $\mathrm{C}-\mathrm{S}, \mathrm{C}-\mathrm{N}, \mathrm{C}=\mathrm{O}$, and $\mathrm{C}-\mathrm{O}$ of cysteine before and after adsorption on surface $\mathrm{Fe} / \mathrm{S}$ of pyrite.

\begin{tabular}{|c|c|c|c|}
\hline \multirow{2}{*}{ Bond } & \multicolumn{2}{|c|}{ Lengths ( } & \multirow{2}{*}{$\Delta \mathrm{d}(\AA)$} \\
\hline & Before Adsorption & After Adsorption & \\
\hline \multirow{2}{*}{$-\mathrm{C}-\mathrm{S}$} & \multirow{2}{*}{1.818} & $1.805(1 \mathrm{~A})$ & -0.013 \\
\hline & & $1.828(1 \mathrm{~B})$ & 0.01 \\
\hline \multirow{2}{*}{$-\mathrm{C}-\mathrm{N}$} & \multirow{2}{*}{1.460} & $1.456(2 \mathrm{~A})$ & -0.004 \\
\hline & & $1.522(2 \mathrm{~B})$ & 0.062 \\
\hline \multirow{2}{*}{$-\mathrm{C}=\mathrm{O}$} & \multirow{2}{*}{1.224} & $1.223(3 \mathrm{~A})$ & -0.001 \\
\hline & & $1.234(3 \mathrm{~B})$ & 0.01 \\
\hline \multirow{2}{*}{$-\mathrm{C}-\mathrm{O}$} & \multirow{2}{*}{1.359} & $1.357(4 \mathrm{~A})$ & -0.002 \\
\hline & & $1.493(4 B)$ & 0.134 \\
\hline
\end{tabular}

\subsection{Adsorption Energies and Mulliken Bond Populations}

\subsubsection{Adsorption Energies}

The adsorption energy $\left(\mathrm{E}_{\mathrm{ad}}\right)$ of cysteine on pyrite surface can be determined using the following equation:

$$
E_{\mathrm{ad}}=\mathrm{E}_{\text {surface }+\mathrm{R}}-\mathrm{E}_{\text {surface }}-\mathrm{E}_{\text {amino acids }}
$$

where $E_{\text {surface }+R}$ is the energy of pyrite slab with the adsorbed cysteine, $E_{\text {surface }}$ is the energy of pyrite slab, and $E_{\text {amino acids }}$ is the energy of cysteine in the slab. The calculated values of cysteine adsorption energies on the pyrite $\left(\begin{array}{lll}1 & 0 & 0\end{array}\right)$ surfaces are displayed in Table 5 . The results show that all the adsorptions are exothermic because all the values in Table 5 are negative. In addition, the adsorption energy of $\mathrm{R}-\mathrm{COOH}-\mathrm{Fe}$ is the largest (absolute value), indicating that this configuration is the most thermodynamically preferred [43], and is in good agreement with the length analysis above.

Table 5. Adsorption energies and Mulliken bond populations of the interaction between cysteine and pyrite $\left(\begin{array}{lll}1 & 0 & 0\end{array}\right)$ surface (negative sign represents exothermic reaction).

\begin{tabular}{cccc}
\hline Optimized Configurations & Bonds & Populations & E $_{\mathbf{a d}}(\mathbf{e V})$ \\
\hline 1A & $-\mathrm{S}-\mathrm{S}$ & - & -0.35 \\
1B & $-\mathrm{S}-\mathrm{Fe}$ & 0.3 & -2.18 \\
2A & $-\mathrm{N}-\mathrm{S}$ & - & -0.62 \\
2B & $-\mathrm{N}-\mathrm{Fe}$ & 0.16 & -2.67 \\
3A & $=\mathrm{O}-\mathrm{S}$ & - & -0.25 \\
3B & $=\mathrm{O}-\mathrm{Fe}$ & 0.27 & -2.16 \\
4A & $-\mathrm{O}-\mathrm{S}$ & - & -1.33 \\
4A & $-{ }^{*}-\mathrm{Ne}$ & 0.16 & -1.33 \\
4B & $-\mathrm{O}-\mathrm{Fe}$ & 0.1 & -2.81 \\
4B & $={ }^{*} \mathrm{O}-\mathrm{Fe}$ & 0.22 & -2.81 \\
4B & $-{ }^{*} \mathrm{~N}-\mathrm{Fe}$ & 0.14 & -2.81 \\
\hline
\end{tabular}

* The atoms near the investigated atom.

\subsubsection{Mulliken Bond Populations}

Table 5 shows the Mulliken bond populations of the interaction between cysteine and pyrite (1 $\left.\begin{array}{ll}0 & 0\end{array}\right)$ surface. The larger the values of the bond population are, the stronger the covalent interactions between cysteine and pyrite $\left(\begin{array}{lll}1 & 0 & 0\end{array}\right)$ surface are [44], while the value is smaller, the stronger ionic bond is [38]. In addition, negative value indicates that the bond is anti-bonding or hydrogen bond. The population values of bonds for sites $\mathrm{Fe}$, including $-\mathrm{S}-\mathrm{Fe},-\mathrm{N}-\mathrm{Fe},=\mathrm{O}-\mathrm{Fe}$, and $-\mathrm{O}-\mathrm{Fe}$, are $0.3,0.16$, 
0.27, and 0.1, respectively. Population values of bonds for sites $\mathrm{S}$, including $-\mathrm{S}-\mathrm{S},-\mathrm{N}-\mathrm{S},=\mathrm{O}-\mathrm{S}$, and -O-S, are not present because their distances are more than $3 \AA$ (Table 3) - too large to form stable bonds. The population values of $-\mathrm{S}-\mathrm{Fe}$ and $=\mathrm{O}-\mathrm{Fe}$ are much larger than those of $-\mathrm{N}-\mathrm{Fe}$ and $-\mathrm{O}-\mathrm{Fe}$, indicating that the bonds of $-\mathrm{S}-\mathrm{Fe}$ and $=\mathrm{O}-\mathrm{Fe}$ tend to be more covalent than $-\mathrm{O}-\mathrm{Fe}$. In addition, when $-\mathrm{O}$ adsorbs on site $\mathrm{S}$, the population value for the bond of the nearby $\mathrm{N}$ and $\mathrm{Fe},-\mathrm{N}-\mathrm{Fe}$ is 0.16 ; when $-\mathrm{O}$ adsorbs on site $\mathrm{Fe}$, that value becomes 0.14 , indicating a greater contribution of site $\mathrm{S}$ than site Fe to the interaction of the nearby $\mathrm{N}$ and Fe.

\subsection{Electron Density Difference of the Interaction between Cysteine and Pyrite $\left(\begin{array}{lll}1 & 0 & 0\end{array}\right)$ Surface}

Figure 4 shows electron density difference results of the interaction between cysteine and pyrite $\left(\begin{array}{lll}1 & 0 & 0\end{array}\right)$ surface. The values of isosurface of the electron density difference are plotted about 0.05 electrons $/ \AA^{3}$. Note that the regions near Fe atoms of sulfide surfaces are blue and regions near $S$ atoms are white. It is clear that electrons transfer from groups of cysteine to Fe of the pyrite $\left(\begin{array}{lll}1 & 0 & 0\end{array}\right)$ surface, and when $-\mathrm{O}$ adsorbs on site $\mathrm{S}$, there are also electrons transferred from $-\mathrm{NH}_{3}$ to Fe atoms, while there are fewer or no electrons transferred between $S$ of pyrite $\left(\begin{array}{lll}1 & 0 & 0\end{array}\right)$ and cysteine, indicating that there is an obvious interaction between cysteine and site Fe, but weak or no bonds formed between cysteine and site S. Figure 4 also shows that the quantity of electrons from -O to Fe is the largest than others, which means the ionic bond of -O-Fe is the strongest and the results are in good agreement with the Mulliken bond populations.

It can be concluded that when the cysteine adsorbs on site Fe, they can form bonds, along with the electron transfer, and when cysteine adsorbs on site $S$, there are no bonds or a very weak interaction between them, so no or few electrons transfer. This implies that the interactions between cysteine and site Fe are mainly chemical, and the interactions between cysteine and site $S$ are mainly physical adsorption. This indicates that the surface chemical speciation has a decisive effect on the adsorption behavior [45]. According to this result, we can just adopt measures to make the proportion of Fe of pyrite $\left(\begin{array}{lll}1 & 0 & 0\end{array}\right)$ larger so that the cells can better adsorb on the pyrite, which can accelerate the bioleaching process. Only the systems that obviously form bonds are analyzed further.

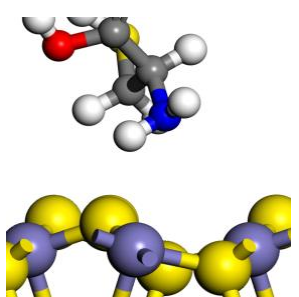

(a) N-S

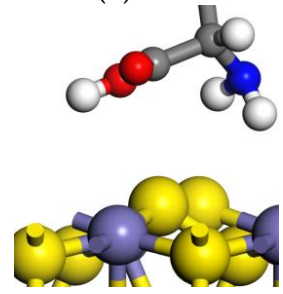

(e) $=\mathrm{O}-\mathrm{S}$

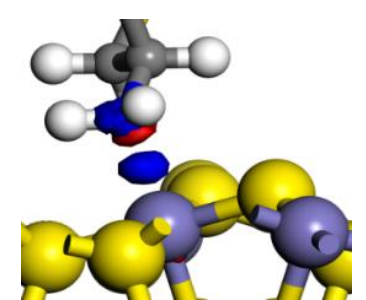

(b) N-Fe

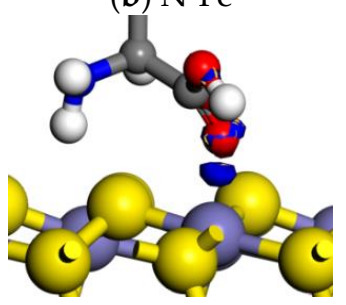

(f) $=\mathrm{O}-\mathrm{Fe}$

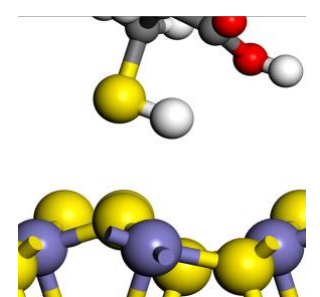

(c) S-S

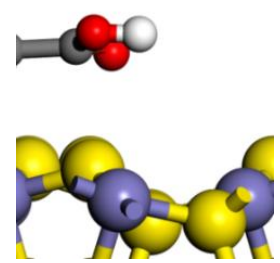

(g) $-\mathrm{O}-\mathrm{S}$

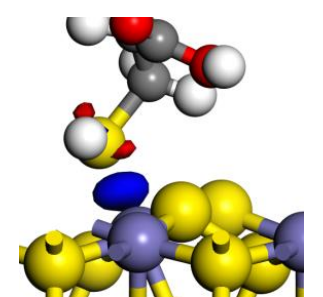

(d) $\mathrm{S}-\mathrm{Fe}$

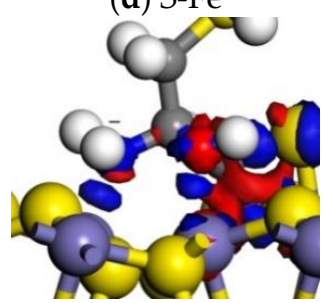

(h) $-\mathrm{O}-\mathrm{Fe}$

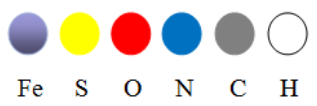

Figure 4. Electron density difference of the interaction between cysteine and pyrite $\left(\begin{array}{lll}1 & 0 & 0\end{array}\right)$ surface. The red area represents losing electrons, and the blue contours indicate an electron density increase, showing with $-\mathrm{NH}_{3}(\mathbf{a}, \mathbf{b}),-\mathrm{SH}(\mathbf{c}, \mathbf{d}),=\mathrm{O}(-\mathrm{C}=\mathrm{O},(\mathbf{e}, \mathbf{f})),-\mathrm{O}(-\mathrm{C}-\mathrm{OH},(\mathbf{g}, \mathbf{h}))$ of cysteine adsorbed on the $\mathrm{S} / \mathrm{Fe}$ site of pyrite $\left(\begin{array}{lll}1 & 0 & 0\end{array}\right)$, respectively. 


\subsection{PDOS of the Interaction between Cysteine and Pyrite (1 00 ) Surface}

Figure 5 shows the projected density of states (PDOS) results of interactions between cysteine and surface atoms of pyrite. The $\mathrm{E}_{\mathrm{F}}$ value, the position of Fermi level, is $0 \mathrm{eV}$. Figure $5 \mathrm{a}-\mathrm{d}$ shows PDOS of the interactions between S 3p and Fe 3d, between N 2p and Fe 3d, between $=\mathrm{O} 2 \mathrm{p}$ and Fe $3 d$, and between - $\mathrm{O} 2 \mathrm{p}$ and $\mathrm{Fe} 3 \mathrm{~d}$ in pyrite $\left(\begin{array}{lll}1 & 0 & 0\end{array}\right)$ surface, respectively. It can be found that a substantial overlap occurred approximately at -8 to $-2 \mathrm{eV}$, while anti-bonding in the range of $0-1 \mathrm{eV}$ is very weak, which resulted in the strong bonding interaction between cysteine and Fe site of pyrite $\left(\begin{array}{lll}1 & 0 & 0\end{array}\right)$ surface [43]. The curves of $=\mathrm{O}-\mathrm{Fe}$ and $-\mathrm{O}-\mathrm{Fe}$ shift down to lower energies compared with N-Fe and $\mathrm{S}-\mathrm{Fe}$, and it can be because of more electrons transfer to $\mathrm{Fe}$ atom when the $=\mathrm{O}$ or $-\mathrm{O}$ atom adsorbs on the Fe site compared to the $\mathrm{N}$ or S atom [24].

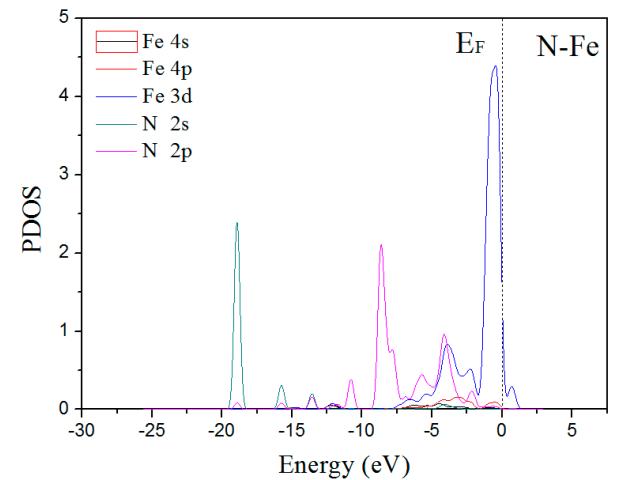

(a)

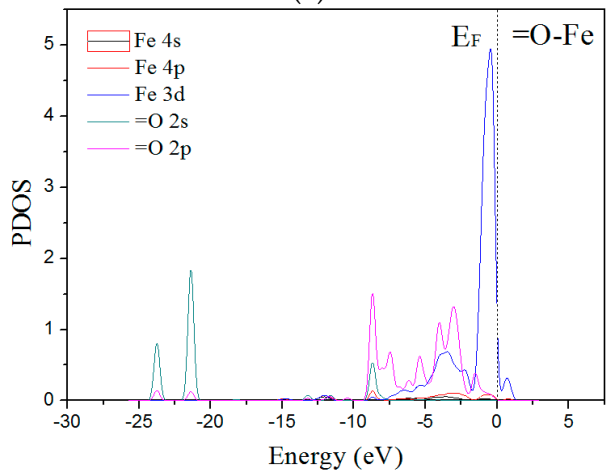

(c)

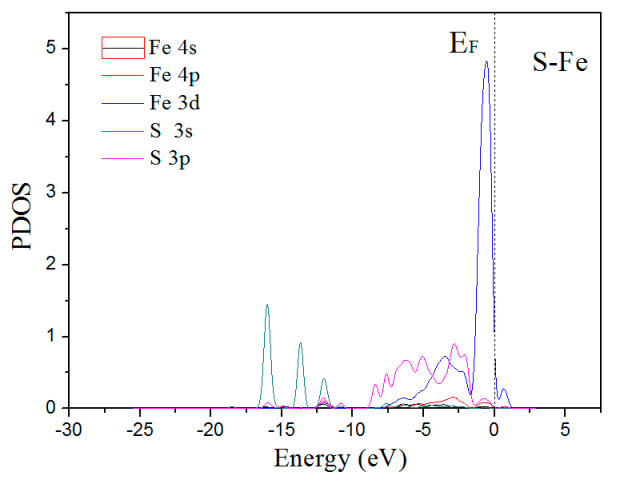

(b)

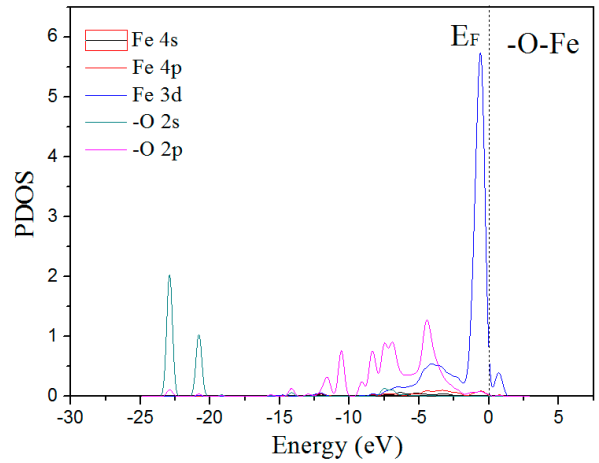

(d)

Figure 5. PDOS analysis for cysteine adsorbs on the pyrite $\left(\begin{array}{lll}1 & 0 & 0\end{array}\right)$, showing with $-\mathrm{NH}_{3}(\mathbf{a}),-\mathrm{SH}(\mathbf{b}),=\mathrm{O}$ $(-\mathrm{C}=\mathrm{O},(\mathbf{c})),-\mathrm{O}(-\mathrm{C}-\mathrm{OH},(\mathbf{d}))$ of cysteine adsorbed on the Fe site of pyrite $\left(\begin{array}{lll}1 & 0 & 0\end{array}\right)$.

\subsection{X-ray Photoelectron Spectroscopy Analysis of Pyrite (1 0 0) Surface Species}

To corroborate the adsorption model sketched in Figure 3, a detailed analysis of the identity of the surface species most likely responsible for cysteine adsorption on pyrite $\left(\begin{array}{lll}1 & 0 & 0\end{array}\right)$ was conducted by XPS spectroscopy. The survey (full range) XPS spectra and the high-resolution XPS spectra of pyrite (1 $\left.\begin{array}{ll}0 & 0\end{array}\right)$ surface species before and after adsorption of cysteine are shown in Figures 6-8, respectively.

The atomic concentrations derived from the survey spectra for samples before and after adsorption cysteine are shown in Table 6. The results show that the most abundant element in the samples is carbon, contributing to $30.7 \%$ and $35.1 \%$ of the pyrite surface elements. A small amount of the carbon may come from the cysteine but most of the carbon was from adventitious carbon, taking into account no carbon in the original pyrite according to the ICP-AES and EDS analysis (Section 2.2). Oxygen is also abundant in the samples, which may come from different sources including oxides, adsorbed cysteine, and water. An increase of nitrogen and sulfur, but decrease of iron, was observed in the sample after 
adsorption of cysteine. According to the results above, it can be inferred that the adsorption of the cysteine took place on the pyrite $\left(\begin{array}{lll}1 & 0 & 0\end{array}\right)$ surface.

Figure 7 shows C 1s, S 2p, and Fe 2p XPS spectra for pyrite $\left(\begin{array}{lll}1 & 0 & 0\end{array}\right)$ before adsorption. The peak at $284.6 \mathrm{eV}$ in Figure $7 \mathrm{a}$ is dominant by $\mathrm{C}$ functional groups including $\mathrm{C}-\mathrm{C} / \mathrm{C}-\mathrm{H}, \mathrm{C}-\mathrm{O}$, and COOThat peak is characteristic of adventitious organic carbon. The Figure $7 \mathrm{~b}$ shows that the two main peaks located at $162.4 \mathrm{eV}$ and $163.6 \mathrm{eV}$ appeared to be from S $2 \mathrm{p}$ spin-orbit doublet $\left(\mathrm{S} 2 \mathrm{p}_{3 / 2}\right.$ and $\mathrm{S}$ $2 \mathrm{p}_{1 / 2}$, respectively), with a splitting of $1.19 \mathrm{eV}$. The spectra contain the main peak at $162.4 \mathrm{eV}$, and the weak shoulder peak at $161.4 \mathrm{eV}$, which can be ascribed to disulfide $\left(\mathrm{S}_{2}{ }^{2-}\right)$ and monosulfide $\left(\mathrm{S}^{2-}\right)$ species, respectively [46-48]. The distribution of sulfur species on pyrite $\left(\begin{array}{lll}1 & 0 & 0\end{array}\right)$ surface (Table 7) shows that the percentages of monosulfide and disulfide are $10.9 \%$ and $89.1 \%$ (atomic percent), respectively. This indicates that the sulfur species on pyrite $\left(\begin{array}{lll}1 & 0 & 0\end{array}\right)$ surface are mainly disulfide, with a small amount of monosulfide. In addition to S 2p XPS spectra, Fe 2p3/2 XPS spectra at $706.8 \mathrm{eV}$ and $711.2 \mathrm{eV}$ (Figure 7c) can also be utilized to characterize the states of pyrite $\left(\begin{array}{ll}1 & 0\end{array}\right)$ surface. Therefore, the results of XPS analysis are in good agreement with the results of the DFT calculation.

Figure 8 shows that, besides the fine XPS spectra of C 1s, S 2p, and Fe 2p, it also detects N 1s XPS spectra for pyrite ( $\left.\begin{array}{lll}1 & 0 & 0\end{array}\right)$ after adsorption of cysteine [49], indicating that adsorption of cysteine occurred. The relative results of the quantification of sulfur species show that the percentages of monosulfide $\left(\mathrm{S}^{2-}\right)$ and disulfide $\left(\mathrm{S}_{2}{ }^{2-}\right)$ were $18.5 \%$ and $67.1 \%$, respectively, and polysulfide $\left(\mathrm{S}_{\mathrm{n}}{ }^{2-}\right)$ was detected at $14.4 \%$. The polysulfide may be formed from monosulfide $\left(\mathrm{S}^{2-}\right)$ and disulfide $\left(\mathrm{S}_{2}{ }^{2-}\right)$, which should be tested further. Compared to the spectra for the pyrite $\left(\begin{array}{ll}1 & 0\end{array}\right)$ surface before adsorption, the monosulfide $\left(\mathrm{S}^{2-}\right)$ species increased from $10.9 \%$ to $18.5 \%$ and disulfide decreased from $89.1 \%$ to $67.1 \%$, indicating that adsorption of cysteine occurred, and such adsorption has led to significant changes in the distribution of the surface sulfur species. Compared to before adsorption, the $S 2 p$ spectrum (Figure $8 \mathrm{~b}$ ) for pyrite (1 000 apparently changed) after adsorption of cysteine, with the binding energy decreasing by $0.4 \mathrm{eV}$. However, for the Fe 2p spectrum (Figure 8c) of pyrite $\left(\begin{array}{lll}1 & 0 & 0\end{array}\right)$ after adsorption of cysteine, there was a shift towards higher binding energy, indicating that electrons were transferred to Fe or that iron was partly oxidized, which corresponds to the chemical bonding between surface Fe of pyrite $\left(\begin{array}{lll}1 & 0 & 0\end{array}\right)$ and cysteine. These results corroborate the results of the DFT calculation.

To further confirm cysteine adsorption on the pyrite $\left(\begin{array}{lll}1 & 0 & 0\end{array}\right)$ surface and assess the chemical state of the cysteine upon adsorption, the high-resolution XPS spectra of the $\mathrm{N}$ elements are determined. Figure $8 \mathrm{~d}$ shows high-resolution $\mathrm{N}$ 1s spectra for the pyrite $\left(\begin{array}{lll}1 & 0 & 0\end{array}\right)$ surface sample, with four deconvoluted peaks at BEs of 398.4, 399.4, 399.8, and $400.5 \mathrm{eV}$. This indicates that the $\mathrm{N} 1 \mathrm{~s}$ signal detected by the survey scan is due to the cysteine adsorption [49].
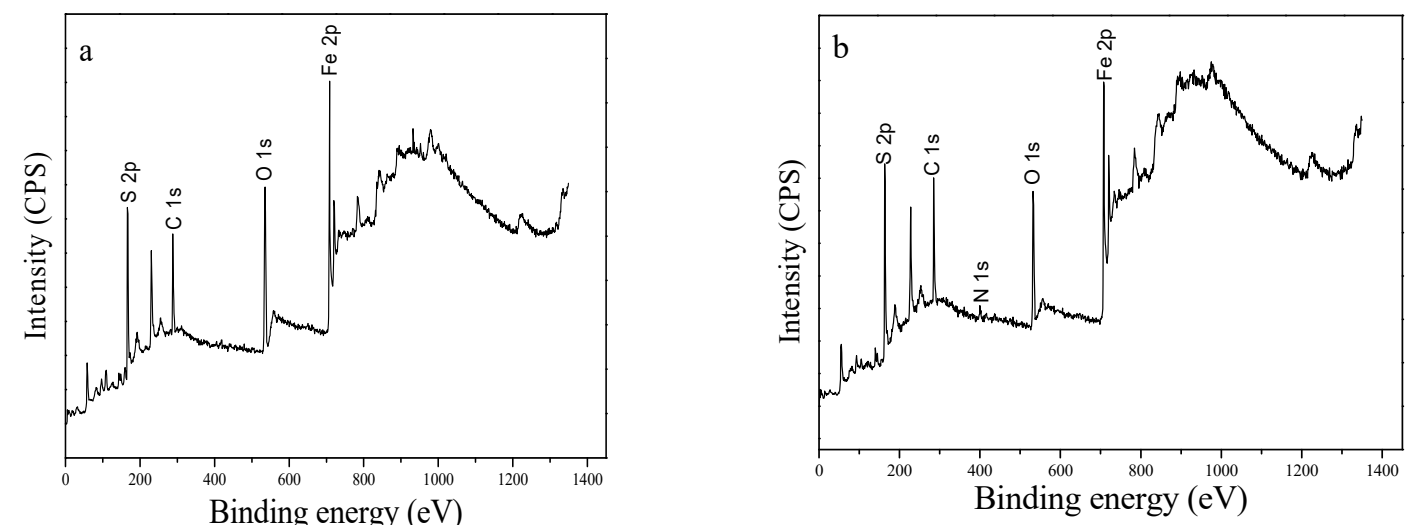

Figure 6. Full range of XPS spectra of pyrite $\left(\begin{array}{lll}1 & 0 & 0\end{array}\right)$ surface samples before (a) and after (b) cysteine adsorption. 

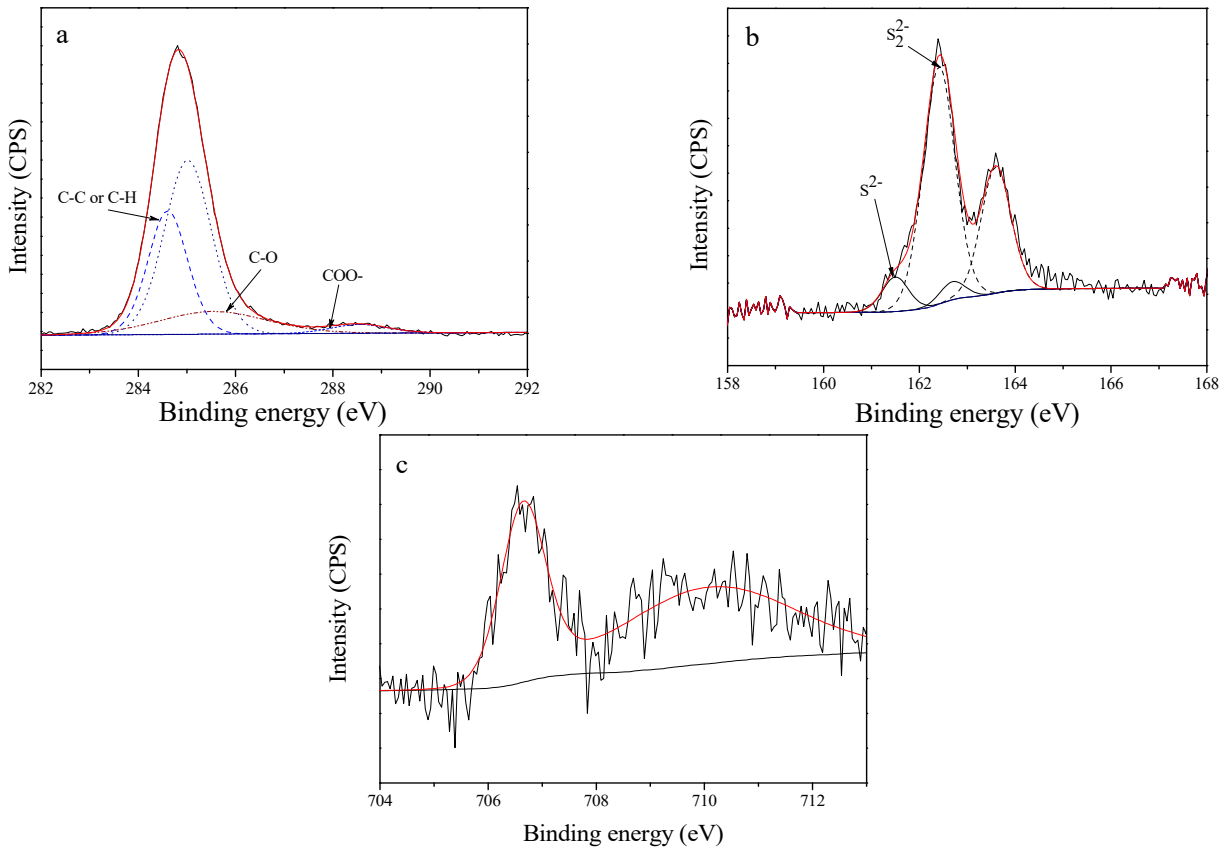

Figure 7. Carbon 1s (a), sulfur $2 p(\mathbf{b})$, and iron $2 p_{3 / 2}$ (c) XPS spectra of pyrite $\left(\begin{array}{lll}1 & 0 & 0\end{array}\right)$ before adsorption of cysteine.
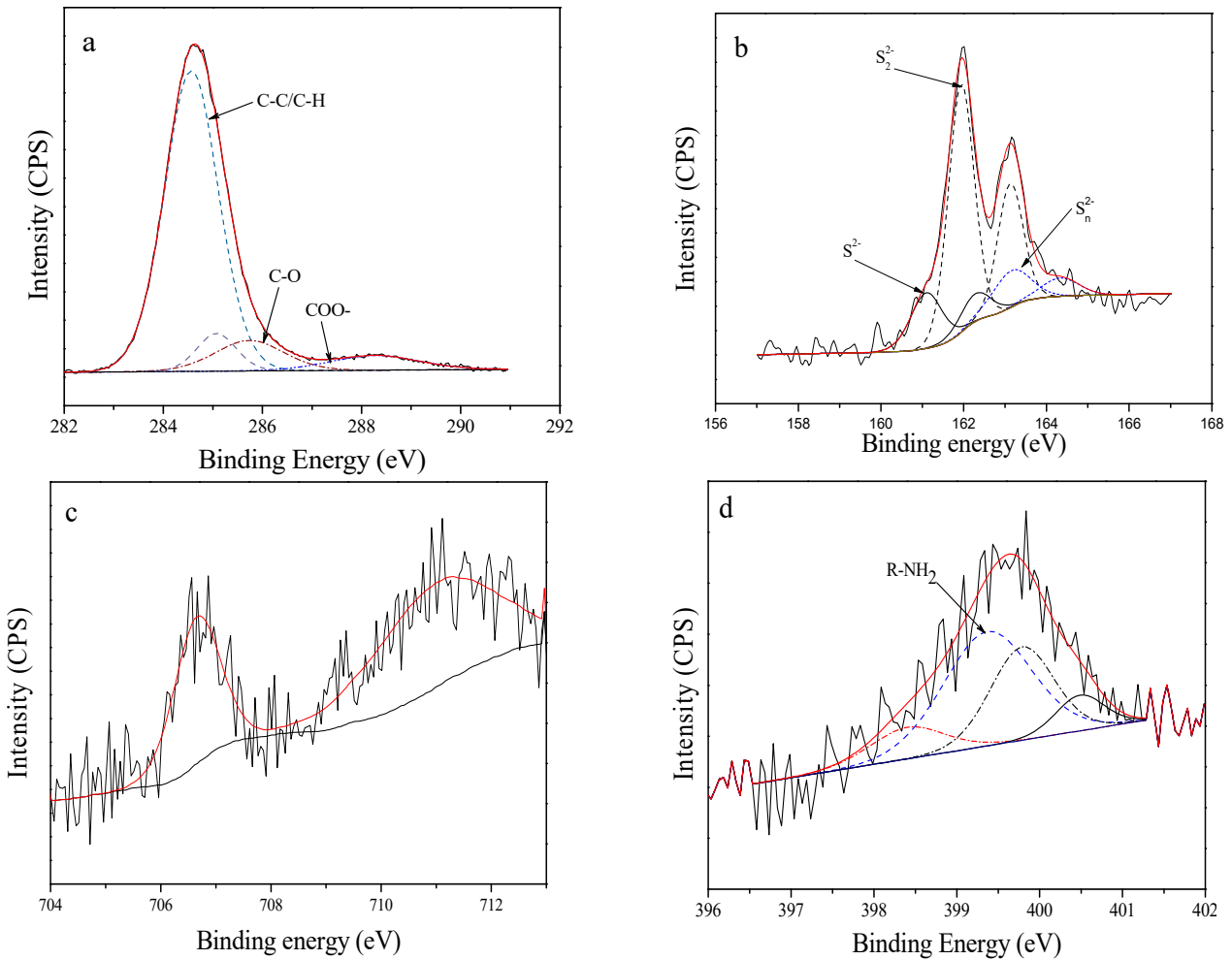

Figure 8. Carbon $1 \mathrm{~s}(\mathbf{a})$, sulfur $2 p(\mathbf{b})$, iron $2 p_{3 / 2}$ (c) and nitrogen 1 s (d) XPS spectra of cysteine adsorption on pyrite $\left(\begin{array}{lll}1 & 0 & 0\end{array}\right)$. 
Table 6. Atomic concentrations (\%) of elements on the surface of pyrite $\left(\begin{array}{lll}1 & 0 & 0\end{array}\right)$ before and after adsorption of cysteine.

\begin{tabular}{cccccc}
\hline & $\mathbf{C}$ & $\mathbf{N}$ & $\mathbf{O}$ & $\mathbf{S}$ & $\mathbf{F e}$ \\
\hline $\begin{array}{c}\text { Before } \\
\text { Adsorption } \\
\text { After }\end{array}$ & 30.7 & - & 30.9 & 26.6 & 11.8 \\
Adsorption & 35.1 & 3.6 & 20.4 & 30.5 & 10.4 \\
\hline
\end{tabular}

Table 7. Atomic concentrations (\%) of different sulfur species on pyrite $\left(\begin{array}{lll}1 & 0 & 0\end{array}\right)$ surface before and after adsorption of cysteine.

\begin{tabular}{cccc}
\hline & $\mathbf{S}_{\mathbf{2}}{ }^{\mathbf{2}}$ & $\mathbf{S}^{\mathbf{2}}$ & $\mathbf{S}_{\mathbf{n}}{ }^{2-}$ \\
\hline Before Adsorption & 89.1 & 10.9 & - \\
After Adsorption & 67.1 & 18.5 & 14.4 \\
\hline
\end{tabular}

\section{Conclusions}

The interfacial interaction between pyrite surface and different groups of cysteine, including -SH, $-\mathrm{NH}_{3}^{+}$, and $-\mathrm{COOH}$, was systematically studied using DFT calculation and XPS measurements in this work; we obtained the interaction orbitals, the optimized adsorption configurations, the adsorption energies, the types of bonds, the direction of the electrons transfer, and the projected density of states when cysteine adsorbed on the pyrite $\left(\begin{array}{ll}1 & 0\end{array}\right)$. These results provide an alternative way of understanding the interfacial interaction between microbes and sulfide mineral surface at the quantum level and give us a method that is simple and effective for evaluating the interfacial interaction.

From the DFT calculation, it was found that the cysteine adsorbs strongly on the Fe of pyrite ( $\left.\begin{array}{lll}1 & 0 & 0\end{array}\right)$ mainly by chemical bonding, while on the $S$ of pyrite $\left(\begin{array}{lll}1 & 0 & 0\end{array}\right)$ it is mainly by physical adsorption. It may be concluded that the pyrite can accept electrons from cysteine, and Fe of pyrite $\left(\begin{array}{lll}1 & 0 & 0\end{array}\right)$ surface is lacking electrons while $S$ of pyrite $\left(\begin{array}{lll}1 & 0 & 0\end{array}\right)$ surface is electronegative, so cysteine can adsorb on the Fe site by chemical bonding. The XPS spectra qualitatively confirm the presence of cysteine adsorption on the pyrite $\left(\begin{array}{lll}1 & 0 & 0\end{array}\right)$ surface. These results not only help us understand the mechanism of cells adsorbing on the pyrite, but also give us a possible way to improve the rate of bioleaching, which is meaningful for the commercial process.

Author Contributions: J.X., H.Y., X.Z., and X.P. conceived of and designed the experiments; X.Z., X.P., L.L., and Z.N. performed the experiments; X.Z. and X.P. analyzed the data; X.Z., X.P., Y.Y., and J.X. wrote the paper.

Funding: National Natural Science Foundation of China (Grant No. 51774342), the joint Funds of National Natural Science Foundation of China and Liaoning Provincial People's Government (Grant No. U1608254), and the Beijing Synchrotron Radiation Facility Public User Program (2016-BEPC-PT-000332).

Acknowledgments: We are grateful to the staff at beamlines 4B9B of Beijing Synchrotron Radiation Facility (BSRF) for their help with beamlines operation and data collection, and the anonymous reviewers for their meticulous checking and helpful suggestions to the manuscript. The calculations were performed at National Supercomputer Centers in Lvliang and Shenzhen of China.

Conflicts of Interest: The authors declare no conflict of interest.

\section{References}

1. Brierley, C.L. Biohydrometallurgical prospects. Hydrometallurgy 2010, 104, 324-328. [CrossRef]

2. Schippers, A.; Sand, W. Bacterial leaching of metal sulfides proceeds by two indirect mechanisms via thiosulfate or via polysulfides and sulfur. Appl. Environ. Microbiol. 1999, 65, 319-321. [PubMed]

3. Panda, S.; Akcil, A.; Pradhan, N.; Deveci, H. Current scenario of chalcopyrite bioleaching: A review on the recent advances to its heap-leach technology. Bioresour. Technol. 2015, 196, 694-706. [CrossRef] [PubMed] 
4. Vera, M.; Schippers, A.; Sand, W. Progress in bioleaching: Fundamentals and mechanisms of bacterial metal sulfide oxidation-Part A. Appl. Microbiol. Biotechnol. 2013, 97, 7529-7541. [CrossRef] [PubMed]

5. Dong, H.L. Mineral-microbe interactions: A review. Front. Earth Sci. China 2010, 4, 127-147. [CrossRef]

6. Nie, Z.Y.; Liu, H.C.; Xia, J.L.; Yang, Y.; Zhen, X.J.; Zhang, L.J.; Qiu, G.Z. Evidence of cell surface iron speciation of acidophilic iron-oxidizing microorganisms in indirect bioleaching process. Biometals 2016, 29, 25-37. [CrossRef] [PubMed]

7. Zhang, R.Y.; Bellenberg, S.; Castro, L.; Neu, T.R.; Sand, W.; Vera, M. Colonization and biofilm formation of the extremely acidophilic archaeon Ferroplasma acidiphilum. Hydrometallurgy 2014, 150, 245-252. [CrossRef]

8. Zhang, R.Y.; Neu, T.R.; Zhang, Y.; Bellenberg, S.; Kuhlicke, U.; Li, Q.; Sand, W.; Vera, M. Visualization and analysis of EPS glycoconjugates of the thermoacidophilic archaeon Sulfolobus metallicus. Appl. Microbiol. Biotechnol. 2015, 99, 7343-7356. [CrossRef] [PubMed]

9. Ganbaatar, N.; Matsuzaki, N.; Nakazawa, Y.; Afrin, R.; Aono, M.; Yano, T.; Hayashi, T.; Hara, M. Surface force analysis of pyrite $\left(\mathrm{FeS}_{2}\right)$ : Its reactivity to amino acid adsorption. Adv. Mater. Phys. Chem. 2016, 6, 167-176. [CrossRef]

10. Nair, N.N.; Schreiner, E.; Marx, D. Glycine at the pyrite-water interface: The role of surface defects. J. Am. Chem. Soc. 2006, 128, 13815-13826. [CrossRef] [PubMed]

11. Trifonov, E.N. Elucidating sequence codes: Three codes for evolution. Ann. N. Y. Acad. Sci. 1999, 870, 330-338. [CrossRef] [PubMed]

12. Trifonov, E.N. Glycine clock: Eubacteria first, archaea next, protoctista, fungi, planta and animalia at last. Gene Ther. Mol. Biol. 1999, 4, 313-322.

13. Chi, Q.J.; Zhang, J.D.; Nielsen, J.U.; Friis, E.P.; Chorkendorff, I.; Canters, G.W.; Andersen, J.E.T.; Ulstrup, J. Molecular monolayers and interfacial electron transfer of Pseudomonas aeruginosa azurin on Au(111). J. Am. Chem. Soc. 2000, 122, 4047-4055. [CrossRef]

14. Zhang, J.D.; Chi, Q.J.; Kuznetsov, A.M.; Hansen, A.G.; Wackerbarth, H.; Christensen, H.E.M.; Andersen, J.E.T.; Ulstrup, J. Electronic properties of functional biomolecules at metal/aqueous solution interfaces. J. Phys. Chem. B 2002, 106, 1131-1152. [CrossRef]

15. Zheng, H.A.; Zhang, C.; Wu, Y.; Shi, P.H.; Wang, Z.H.; Wang, X.J.; Li, B.Y.; Liu, J.; Xie, X.H. Bioleaching of arsenic-containing gold ore influenced by cysteine. Fresenius Environ. Bull. 2015, 24, 379-385.

16. Ghosh, B.; Mukhopadhyay, B.P.; Bairagya, H.R. Effect of amino acids on bioleaching of chalcopyrite ore by Thiobacillus ferrooxidans. Afr. J. Biotechnol. 2012, 11, 1991-1996. [CrossRef]

17. He, Z.G.; Gao, F.L.; Zhong, H.; Hu, Y.H. Effects of L-cysteine on Ni-Cu sulfide and marmatite bioleaching by Acidithiobacillus caldus. Bioresour. Technol. 2009, 100, 1383-1387. [CrossRef] [PubMed]

18. Wang, Z.H.; Xie, X.H.; Xiao, S.M.; Liu, J.S. Comparative study of interaction between pyrite and cysteine by thermogravimetric and electrochemical techniques. Hydrometallurgy 2010, 101, 88-92. [CrossRef]

19. He, Z.G.; Zhao, J.C.; Liang, W.J.; Hu, Y.H.; Qiu, G.Z. Effect of L-cysteine on bioleaching of Ni-Cu sulphide by A. manzaensis. J. Cent. South Univ. 2011, 18, 381-385. [CrossRef]

20. Yang, Y.J.; Liu, J.; Liu, F.; Wang, Z.; Miao, S. Molecular-level insights into mercury removal mechanism by pyrite. J. Hazard. Mater. 2017, 344, 104-112. [CrossRef] [PubMed]

21. Chen, J.H.; Li, Y.Q.; Zhao, C.H. First principles study of the occurrence of gold in pyrite. Comp. Mater. Sci. 2014, 88, 1-6. [CrossRef]

22. Chen, J.H.; Long, X.; Chen, Y. Comparison of multilayer water adsorption on the hydrophobic galena (PbS) and hydrophilic pyrite $\left(\mathrm{FeS}_{2}\right)$ surfaces: A DFT study. J. Phys. Chem. C 2014, 118, 11657-11665. [CrossRef]

23. Li, Q.; Qin, W.Q.; Sun, W.; Qiu, G.Z. Calculation of electron structure by density function theory and electrochemical process of surface (100) of $\mathrm{FeS}_{2}$. J. Cent. South Univ. 2007, 14, 618-622. [CrossRef]

24. Zhao, C.H.; Chen, J.H.; Li, Y.Q.; Chen, Y.; Li, W.Z. First-principle calculations of interaction of $\mathrm{O}_{2}$ with pyrite, marcasite and pyrrhotite surfaces. Trans. Nonferrous Met. Soc. China 2016, 26, 519-526. [CrossRef]

25. Sanchez-Arenillas, M.; Mateo-Marti, E. Pyrite surface environment drives molecular adsorption: Cystine on pyrite(100) investigated by X-ray photoemission spectroscopy and low energy electron diffraction. Phys. Chem. Chem. Phys. 2016, 18, 27219-27225. [CrossRef] [PubMed]

26. Mateo-Marti, E.; Sanchez-Arenillas, M. Spectroscopic study of amino acids adsorption on pyrite surface: From vacuum to solution conditions. Eur. Planet. Chem. Phys. 2015, 458, 92-98.

27. Von Oertzen, G.U.; Harmer, S.L.; Skinner, W.M. XPS and ab initio calculation of surface states of sulfide minerals: Pyrite, chalcopyrite and molybdenite. Mol. Simul. 2006, 32, 1207-1212. [CrossRef] 
28. Von Oertzen, G.U.; Skinner, W.M.; Nesbitt, H.W.; Pratt, A.R.; Buckley, A.N. Cu adsorption on pyrite(100): $\mathrm{Ab}$ initio and spectroscopic studies. Surf. Sci. 2007, 601, 5794-5799. [CrossRef]

29. Yang, B.; Tong, X.; Deng, Z.B.; Lv, X.W. The adsorption of Cu species onto pyrite surface and its effect on pyrite flotation. J. Chem. 2016, 2016, 4627929. [CrossRef]

30. Murphy, R.; Strongin, D.R. Surface reactivity of pyrite and related sulfides. Surf. Sci. Rep. 2009, $64,1-45$. [CrossRef]

31. Qiu, G.Z.; Xiao, Q.; Hu, Y.H.; Qin, W.Q.; Wang, D.Z. Theoretical study of the surface energy and electronic structure of pyrite $\mathrm{FeS}_{2}$ using a total-energy pseudopotential method, CASTEP. J. Colloid Interf. Sci. 2004, 270, 127-132. [CrossRef]

32. Segall, M.D.; Lindan, P.J.D.; Probert, M.J.; Pickard, C.J.; Haanip, P.J.; Clark, S.J.; Payne, M.C. First-principles simulation: Ideas, illustrations and the CASTEP code. J. Phys.-Condens. Matter 2002, 14, 2717-2744. [CrossRef]

33. Perdew, J.P.; Burke, K.; Ernzerhof, M. Generalized gradient approximation made simple. Phys. Rev. Lett. 1996, 77, 3865-3868. [CrossRef] [PubMed]

34. Vanderbilt, D. Soft self-consistent pseudopotentials in a generalized eigenvalue formalism. Phys.Rev. B 1990, 41, 7892-7895. [CrossRef]

35. Blanchard, M.; Wright, K.; Gale, J.D.; Catlow, C.R.A. Adsorption of $\mathrm{As}(\mathrm{OH})_{3}$ on the (001) surface of $\mathrm{FeS}_{2}$ pyrite: A quantum-mechanical DFT study. J. Phys. Chem. C 2007, 111, 11390-11396. [CrossRef]

36. Li, Y.Q.; Chen, J.H.; Guo, J. DFT study of influences of As, Co and Ni impurities on pyrite (100) surface oxidation by $\mathrm{O}_{2}$ molecule. Chem. Phys. Lett. 2011, 511, 389-392. [CrossRef]

37. Herbert, F.W.; Krishnamoorthy, A.; Ma, W.; Van Vliet, K.J.; Yildiz, B. Dynamics of point defect formation, clustering and pit initiation on the pyrite surface. Electrochimica Acta 2014, 127, 416-426. [CrossRef]

38. Zhang, X.R.; Qian, Z.B.; Zheng, G.B.; Zhu, Y.G.; Wu, W.G. The design of a macromolecular depressant for galena based on DFT studies and its application. Miner. Eng. 2017, 112, 50-56. [CrossRef]

39. Xian, Y.J.; Nie, Q.; Wen, S.M.; Liu, J.; Deng, J.S. Investigation of pyrite surface state by DFT and AFM. J. Cent. South Univ. 2015, 22, 2508-2514. [CrossRef]

40. Hung, A.; Yarovsky, I.; Russo, S.P. Density-functional theory studies of xanthate adsorption on the pyrite $\mathrm{FeS}_{2}$ and (111) surfaces. J. Chem. Phys. 2003, 118, 6022-6029. [CrossRef]

41. Sauer, J.; Sustmann, R. Mechanistic aspects of Diels-Alder reactions: A critical survey. Angew. Chem. Int. Ed. 1980, 19, 779-807. [CrossRef]

42. Rajaraman, G.; Caneschi, A.; Gatteschi, D.; Totti, F. A periodic mixed gaussians-plane waves DFT study on simple thiols on $\mathrm{Au}(111)$ : Adsorbate species, surface reconstruction, and thiols functionalization. Phys. Chem. Chem. Phys. 2011, 13, 3886-3895. [CrossRef] [PubMed]

43. Li, K.; Zhao, Y.L.; Zhang, P.; He, C.H.; Deng, J.; Ding, S.J.; Shi, W.Q. Combined DFT and XPS investigation of iodine anions adsorption on the sulfur terminated (001) chalcopyrite surface. Appl. Surf. Sci. 2016, 390, 412-421. [CrossRef]

44. Zhao, C.H.; Chen, J.H.; Li, Y.Q.; Huang, D.W.; Li, W.Z. DFT study of interactions between calcium hydroxyl ions and pyrite, marcasite, pyrrhotite surfaces. Appl. Surf. Sci. 2015, 355, 577-581. [CrossRef]

45. Ling, W.B.; Wang, L.; Liu, H.C.; Nie, Z.Y.; Yang, Y.; Yang, H.Y.; Ma, C.Y.; Zheng, L.; Zhao, Y.D.; Xia, J.L. The evidence of decisive effect of both surface microstructure and speciation of chalcopyrite on attachment behaviors of extreme thermoacidophile Sulfolobus metallicus. Minerals 2018, 8, 159. [CrossRef]

46. Harmer, S.L.; Pratt, A.R.; Nesbitt, W.H.; Fleet, M.E. Sulfur species at chalcopyrite $\left(\mathrm{CuFeS}_{2}\right)$ fracture surfaces. Am. Mineral. 2004, 89, 1026-1032. [CrossRef]

47. Harmer, S.L.; Thomas, J.E.; Fornasiero, D.; Gerson, A.R. The evolution of surface layers formed during chalcopyrite leaching. Geochim. Cosmochim. Acta 2006, 70, 4392-4402. [CrossRef]

48. Zhu, J.X.; Xian, H.Y.; Lin, X.J.; Tang, H.M.; Du, R.X.; Yang, Y.P.; Zhu, R.L.; Liang, X.L.; Wei, J.M.; Teng, H.H. Surface structure-dependent pyrite oxidation in relatively dry and moist air: Implications for the reaction mechanism and sulfur evolution. Geochim. Cosmochim. Acta 2018, 228, 259-274. [CrossRef]

49. Yoshinari, M.; Oda, Y.; Ueki, H.; Yokose, S. Immobilization of bisphosphonates on surface modified titanium. Biomaterials 2001, 22, 709-715. [CrossRef]

(C) 2018 by the authors. Licensee MDPI, Basel, Switzerland. This article is an open access article distributed under the terms and conditions of the Creative Commons Attribution (CC BY) license (http://creativecommons.org/licenses/by/4.0/). 